\title{
Perbedaan Kadar Feritin Serum pada Penyandang Talasemia $\beta$ Mayor yang Mengalami Hipotiroid dan Eutiroid
}

Burhan, Susi Susanah, Sri Sudarwati

Bagian Ilmu Kesehatan Anak Fakultas Kedokteran Universitas Padjadjaran/RSUP Dr. Hasan Sadikin, Bandung

Latar belakang. Komplikasi penumpukan besi pada organ tiroid berupa hipotiroid. Sebagian besar penelitian yang meneliti hubungan feritin serum dan hipotiroid mendapatkan hasil yang tidak bermakna. Penumpukan besi pada organ dapat dipengaruhi oleh faktor genetik sehingga menyebabkan perbedaan hasil penelitian.

Tujuan. Menentukan perbedaan feritin serum pada penyandang talasemia $\beta$ mayor dengan hipotiroid dan eutiroid.

Metode. Jenis penelitian ini adalah analitik observasional rancangan cross sectional pada penyandang talasemia $\beta$ mayor di poliklinik anak Hemato-Onkologi RSUP Dr. Hasan Sadikin. Subjek diperiksakan TSH, FT4, T3 dan feritin, dibagi menjadi kelompok hipotiroid dan eutiroid, kemudian diklasifikasikan menjadi hipotiroid nyata, subklinis, sekunder dan eutiroid. Analisis menggunakan Uji Mann Whitney dan Kruskall Wallis.

Hasil. Subjek penelitian 68 anak, 38 subjek (55\%) mengalami hipotiroid. Feritin serum kelompok hipotiroid 3275 ng/dL, berbanding $3648 \mathrm{ng} / \mathrm{dL}$ pada eutiroid, tidak berbeda bermakna $(\mathrm{p}=0,443)$. Terdapat hubungan feritin serum dengan klasifikasi hipotiroid. Feritin serum berdasarkan klasifikasi hipotiroid nyata, subklinis, sekunder dan eutiroid secara berurutan sebesar 6575, 2687, 4089, dan 3648 $\mathrm{ng} / \mathrm{mL}(\mathrm{p}=0,027)$. Analisis posthoc mendapatkan hipotiroid nyata dan subklinis berbeda bermakna.

Kesimpulan. Hasil penelitian ini menunjukkan feritin serum tidak berbeda pada kelompok hipotiroid dan eutiroid, tetapi berbeda pada hipotiroid nyata dan subklinis. Hasil penelitian mendorong dilakukan evaluasi profil tiroid secara rutin sejak dini. Sari Pediatri 2017;19(3):161-5

Kata kunci: talasemia $\beta$ mayor, feritin, hipotiroid

\section{Differences of Serum Ferritin Levels in $\beta$-Thalassemia Major Patients with Hypothyroid and Euthyroid}

Burhan, Susi Susanah, Sri Sudarwati

Background. One of the complications in the thyroid organs is hypothyroid. Most of the studies that examined serum ferritin and hypothyroid levels had no significant results. The accumulation of iron in organs can be influenced by genetic factors resulting in different research results.

Objective. To know the difference of serum ferritin level in $\beta$-thalassemia major patient with hypothyroid and euthyroid

Methods. The type of this study was observational analytic with cross sectional design on $\beta$-thalassemia major patient in outpatient clinic Hemato-Oncology Dr. Hasan Sadikin General Hospital. Research subjects were examined TSH, FT4, T3 and ferritin, then divided into hypothyroid and euthyroid groups, classified into overt hypothyroid, subclinical hypothyroid, secondary hypothyroid and euthyroid. The analysis using Mann Whitney Test and Kruskall Wallis Test

Results. Research subjects were 68 children, 38 subjects (55\%) hypothyroid. A median ferritin of the hypothyroid group 3275 ng / $\mathrm{dL}$, versus $3648 \mathrm{ng} / \mathrm{dL}$ (885-11757) in the euthyroid group, there was no significant difference $(\mathrm{p}=0.443)$. There is a relationship between serum ferritin levels and hypothyroid classification. Serum ferritin levels based on classification overt hypothyroid, subclinical hypothyroid, secondary hypothyroid and euthyroid were respectively $6575,2687,4089$, and $3648 \mathrm{ng} / \mathrm{mL}$ (p = 0.027). In posthoc analysis, there was a difference in serum ferritin levels in overt hypothyroid and subclinical hypothyroid.

Conclusion. The results of this study indicate that serum ferritin levels are not different in thalassemia with hypothyroid and euthyroid, but have differences between overt hypothyroid and subclinical hypothyroidism. The results of this study support the evaluation of thyroid profile on a regular basis early. Sari Pediatri 2017;19(3):161-5

Keywords: major $\beta$ thalassemia, ferritin, hypothyroid

Alamat korespondensi: Dr. Burhan. Departemen Ilmu Kesehatan Anak Fakultas Kedokteran UNPAD Rumah Sakit Dr. Hasan Sadikin Bandung Jl. Pasteur no. 38 Bandung, Indonesia 40163. Email: burhan2901@yahoo.com 
$\mathrm{T}$ alasemia $\beta$ mayor diturunkan secara autosomal recessive yang menyebabkan produksi rantai globin $\beta$ rendah sehingga rantai globin $\alpha$ menjadi berlebih. ${ }^{1}$ Pada talasemia $\beta$ mayor terjadi dekstruksi eritrosit prematur pada sumsum tulang (eritropoesis inefektif). Keadaan tersebut menyebabkan peningkatan penyerapan besi pada usus yang mencapai 10 kali lipat dibandingkan pada anak normal. Transfusi berulang akan mempercepat penumpukan besi pada organ seperti jantung, hati, kelenjar endokrin (kelenjar hipofisis, pankreas, paratiroid, dan tiroid). ${ }^{2,3}$ Prevalensi hipotiroid pada talasemia mayor sekitar 7\%-60\%. ${ }^{4}$ Hipotiroid yang terjadi terbagi menjadi hipotiroid primer dan sekunder. $^{2}$

Sebagian besar penelitian yang meneliti hubungan kadar feritin serum dan hipotiroid pada penyandang talasemia mayor menunjukkan hubungan yang tidak signifikan. ${ }^{3-13}$ Hanya sebagian kecil yang mendapatkan hasil yang signifikan. ${ }^{14,15}$ Faktor genetik (polimorfisme) berperan terhadap efek toksik besi pada berbagai organ yang berbeda. Hal tersebut perlu dipikirkan dapat menjadi faktor penyebab perbedaan hasil pada berbagai penelitian. ${ }^{16}$

Tujuan penelitian ini adalah untuk menentukan perbedaan kadar feritin serum pada penyandang talasemia $\beta$ mayor dengan hipotiroid dan eutiroid.

\section{Metode}

Penelitian analitik observasional dengan pendekatan cross sectional dilakukan pada penyandang talasemia $\beta$ mayor usia 5-14 tahun di klinik Hemato-onkologi RSUP Dr. Hasan Sadikin dari bulan mei sampai dengan juni 2017. Transfusi darah didapatkan secara reguler (setiap 14-30 hari) bertujuan untuk menjaga kadar hemoglobin pra transfusi tidak kurang dari $9 \mathrm{~g} / \mathrm{dL}$. Kriteria inklusi penelitian, antara lain, 1) penyandang talasemia $\beta$ mayor bergantung transfusi, 2) usia 5-14 tahun, dan 3) orang tua bersedia anaknya mengikuti penelitian dan menandatangani persetujuan ikut serta dalam penelitian. Kriteria eksklusi penelitian, antara lain, riwayat kelainan fungsi kelenjar tiroid pada pasien atau keluarga, 2) terdapat tanda dan gejala infeksi. Dibutuhkan minimal 68 subjek penelitian. Kemudian dilakukan pencatatan nama, usia, status antropometri, status gizi, jenis obat kelasi besi, dan riwayat kelainan tiroid pada pasien dan keluarga.

Subjek yang memenuhi kriteria penelitian dilakukan pemeriksaan feritin, FT4, T3, dan TSH. Pemeriksaan FT4 dan T3 digunakan metode radioimmuno assay (RIA), sedangkan TSH digunakan immunoradiometric assay (IRMA). Setiap sampel darah dilakukan pemeriksaan sebanyak dua kali (duplo) untuk mendapatkan hasil yang akurat. Subjek kemudian dikelompokkan menjadi kelompok hipotiroid dan kelompok eutiroid. Pemeriksaan feritin menggunakan metode electrochemiluminescence immunoassay (ECLIA).

Kelompok hipotiroid kemudian dipecah kembali sesuai dengan klasifikasi hipotiroid. Hipotiroid nyata didefinisikan terjadi penurunan FT4 disertai peningkatan TSH. Hipotiroid subklinis apabila terjadi peningkatan TSH tanpa disertai penurunan FT4. Hipotiroid sekunder apabila terjadi penurunan FT4 tanpa disertai peningkatan TSH. Eutiroid apabila FT4 dan TSH dalam batas normal. Uji statistik dilakukan dengan uji Mann Whitney dan Kruskall Wallis dikatakan bermakna apabila $\mathrm{p}<0,05$.

\section{Hasil}

Enampuluh delapan anak memenuhi kriteria inklusi. Subjek diperiksakan TSH, T3, dan FT4. Kemudian dibagi 2 kelompok, yaitu kelompok hipotiroid dan normal. Di antara 68 subjek, 38 anak laki laki dan 30 anak perempuan. Hasil menunjukkan bahwa usia kelompok hipotiroid lebih muda daripada kelompok eutiroid. Subjek dengan perawakan pendek lebih banyak pada kelompok hipotiroid. Kelompok yang termasuk kategori wasted tampak lebih banyak pada kelompok normal dibandingkan pada kelompok hipotiroid. Hal tersebut diakibatkan perawakan pendek terjadi, terutama pada kelompok hipotiroid. Sebagian besar subjek penelitian sudah mendapatkan kelasi besi deferipron.

Pada Tabel 2 tampak kadar feritin serum pada kedua kelompok tidak terdapat perbedaan bermakna.Pada Tabel 3 menunjukkan bahwa terdapat hubungan kadar feritin serum dengan klasifikasi hipotiroid $(\mathrm{p}=0,027)$. Pada posthoc didapatkan feritin serum berbeda bermakna antara kelompok hipotiroid nyata dan hipotiroid subklinis ( $\mathrm{p}=0,014)$. 
Burhan $d k k$ : Perbedaan kadar feritin serum pada penyandang talasemia $\beta$ mayor hipotiroid dan eutiroid

Tabel 1. Karakteristik subjek penelitian

\begin{tabular}{|c|c|c|c|}
\hline & $\begin{array}{l}\text { Total } \\
\mathrm{n}=68\end{array}$ & $\begin{array}{c}\text { Hipotiroid } \\
\mathrm{n}=38\end{array}$ & $\begin{array}{c}\text { Normal } \\
\mathrm{n}=30\end{array}$ \\
\hline Usia, med & $\begin{array}{c}10 \text { tahun } 6 \\
\text { bulan } \\
(53-172)\end{array}$ & $\begin{array}{c}7 \text { tahun } 6 \\
\text { bulan }(60 \\
-172)\end{array}$ & $\begin{array}{c}11 \text { tahun } \\
6 \text { bulan } \\
(53-168)\end{array}$ \\
\hline \multicolumn{4}{|l|}{ Usia, tahun, n (\%) } \\
\hline $\begin{array}{l}<10 \\
\geq 10\end{array}$ & $\begin{array}{l}30(44,1) \\
38(55,9)\end{array}$ & $\begin{array}{l}21(55,3) \\
17(44,7)\end{array}$ & $\begin{array}{c}9(30,0) \\
21(70,0)\end{array}$ \\
\hline \multicolumn{4}{|l|}{ Jenis kelamin, n (\%) } \\
\hline $\begin{array}{l}\text { Laki-laki } \\
\text { Perempuan }\end{array}$ & $\begin{array}{l}38(55,9) \\
30(44,1)\end{array}$ & & \\
\hline \multicolumn{4}{|l|}{$\begin{array}{l}\text { Status antropometri, } \\
\text { rerata } \pm S D\end{array}$} \\
\hline $\begin{array}{l}\text { Tinggi badan }(\mathrm{cm}) \\
\text { Berat badan }(\mathrm{kg})\end{array}$ & $\begin{array}{c}120,5 \pm 14,7 \\
23,4 \pm 7,2\end{array}$ & & $\begin{array}{c}125,6 \pm 14,4 \\
25,6 \pm 6,8\end{array}$ \\
\hline \multicolumn{4}{|l|}{$\mathrm{TB} / \mathrm{U}, \mathrm{n}(\%)$} \\
\hline $\begin{array}{l}\text { Normal } \\
\text { Pendek }<2 \text { SD } \\
\text { Amat pendek }<3 \text { S }\end{array}$ & $25(36,8)$ & & $\begin{array}{c}13(43,3) \\
8(26,7) \\
9(30,0)\end{array}$ \\
\hline \multicolumn{4}{|l|}{$\mathrm{BMI} / \mathrm{U}, \mathrm{BB} / \mathrm{TB}$} \\
\hline Normal & $40(5$ & 24 & $16(53,3)$ \\
\hline Wasted & $22(3$ & $10(26,3)$ & $12(40,0)$ \\
\hline Severely u & $4(5$, & $2(5,3)$ & $2(6,7)$ \\
\hline Obesitas & $2(2$ & $2(5,3)$ & $0(0,0)$ \\
\hline \multicolumn{4}{|l|}{ Jenis kelasi besi } \\
\hline Tidak m & 3( & & 1( \\
\hline Def & 49( & 29 & $20(66,7)$ \\
\hline & 15 & & \\
\hline Desferal & $1(1,5)$ & $1(2,6)$ & $0(0,0)$ \\
\hline
\end{tabular}

Tabel 2. Perbedaan kadar feritin serum antara kelompok hipotiroid dengan eutiroid

\begin{tabular}{lccc}
\hline & $\begin{array}{c}\text { Hipotiroid } \\
\mathrm{n}=38\end{array}$ & $\begin{array}{c}\text { Eutiroid } \\
\mathrm{n}=30\end{array}$ & Nilai $\mathrm{p}^{*}$ \\
\hline $\begin{array}{l}\text { Feritin (ng/dL), } \\
\text { median (min- }\end{array} \begin{array}{c}3275(721- \\
10223)\end{array}$ & $\begin{array}{c}3648(885- \\
11757)\end{array}$ & 0,443 \\
maks) & 1023 & \\
\hline $\begin{array}{l}\text { Keterangan: *analisis menggunakan Uji Mann } \\
\text { bermakna apabila } \mathrm{p}<0,05\end{array}$ &
\end{tabular}

\section{Pembahasan}

Kadar feritin serum merupakan petunjuk cadangan besi dalam tubuh. Feritin merupakan suatu reaktan fase akut yang dipengaruhi jenis kelamin, etnis dan ras, inflamasi akut, serta penyakit yang mendasarinya dengan demikian dapat mengganggu interpretasi hasil. ${ }^{17-19}$

Kami mendapatkan prevalensi 55\% karena hampir seluruh subjek penelitian tidak teratur dalam mengonsumsi obat kelasi besi. Hasil tersebut sesuai dengan prevalensi pada penelitian sebelumnya yang berkisar 7\%-60\%. ${ }^{4}$ Perbedaan prevalensi dapat juga diakibatkan oleh faktor genetik. $3,16,20$

Kami mendapatkan usia termuda 5 tahun yang mengalami hipotiroid. Pada penelitian lain didapatkan usia termuda pada usia 4,5 tahun. ${ }^{12}$ Usia yang sangat rendah tersebut mungkin diakibatkan terapi kelasi besi

Tabel 3 Perbedaan kadar feritin antara kelompok hipotiroid nyata, subklinis, sekunder dengan eutiroid

\begin{tabular}{lccccc}
\hline & $\begin{array}{c}\text { Hipotiroid nyata (a) } \\
\mathrm{n}=4\end{array}$ & $\begin{array}{c}\text { Hipotiroid } \\
\text { subklinis }(\mathrm{b}) \\
\mathrm{n}=23\end{array}$ & $\begin{array}{c}\text { Hipotiroid } \\
\text { sekunder }(\mathrm{c}) \\
\mathrm{n}=11\end{array}$ & $\begin{array}{c}\text { Eutiroid (d) } \\
\mathrm{n}=30\end{array}$ & $\begin{array}{c}\text { Nilai } \\
\mathrm{p}^{*}\end{array}$ \\
\hline $\begin{array}{l}\text { Ferritin (ng/dL), } \\
\text { median (min-maks) }\end{array}$ & $\begin{array}{c}6575 \\
(3770-10223)\end{array}$ & $\begin{array}{c}2687 \\
(721-8016)\end{array}$ & $\begin{array}{c}4089 \\
(819-8529)\end{array}$ & $\begin{array}{c}3648 \\
(885-11757)\end{array}$ & 0,027 \\
\hline
\end{tabular}

\footnotetext{
Keterangan:

*analisis menggunakan Uji Kruskall Wallis, dan Uji Mann Whitney *bermakna $\mathrm{p}<0,05$

a vs.b, median feritin serum $3888 \mathrm{ng} / \mathrm{dL}, \mathrm{p}=0,014^{*}$

a vs.c, median feritin serum $2486 \mathrm{ng} / \mathrm{dL}, \mathrm{p}=0,140$

a vs.d, median feritin serum $2927 \mathrm{ng} / \mathrm{dL}, \mathrm{p}=0,066$

b vs.c median feritin serum $-1402 \mathrm{ng} / \mathrm{dL}, \mathrm{p}=0,077$

b vs.d, median feritin serum $-961 \mathrm{ng} / \mathrm{dL}, \mathrm{p}=0,143$

c vs.d, median feritin serum $441 \mathrm{ng} / \mathrm{dL}, \mathrm{p}=0,288$
} 
yang tidak adekuat, anemia kronis, malnutrisi serta faktor polimorfisme. ${ }^{16,21}$

Pada kelompok hipotiroid dan eutiroid, kadar feritin serum tidak berbeda. Hasil tersebut juga sudah dilaporkan oleh penelitian terdahulu. ${ }^{3-13}$ Terdapat beberapa penjelasan mengapa hubungan yang bermakna tidak didapatkan. Penjelasan yang paling mungkin adalah faktor polimorfisme. ${ }^{16}$ Penelitian lain menemukan bahwa Thr92AlaD2 berperan terjadi pada terjadinya hipotiroid. ${ }^{22}$ Kedua hal tersebut dapat menyebabkan hipotiroid dapat terjadi pada penyandang talasemia dengan kadar feritin yang rendah ataupun tidak terjadinya hipotiroid walaupun didapatkan kadar feritin serum yang tinggi.

Terdapat hubungan antara kadar feritin serum dengan klasifikasi hipotiroid. Pada posthoc didapatkan feritin serum berbeda bermakna antara kelompok hipotiroid nyata dan subklinis. Hal tersebut karena kelompok nyata memiliki feritin serum yang jauh lebih tinggi dibandingkan hipotiroid subklinis. Pada perbandingan klasifikasi hipotiroid lainnya, kadar feritin serum tidak berbeda. Hasil tersebut mungkin diakibatkan oleh faktor polimorfisme. Polimorfisme tersebut dapat menyebabkan hipotiroid meskipun dengan kadar feritin yang sama. Hasil tersebut sesuai dengan penelitian sebelumnya yang membandingkan kadar feritin serum kelompok klasifikasi hipotiroid, yaitu hipotiroid nyata dan subklinis yang dibandingkan dengan kelompok eutiroid. Namun, belum ada penelitian yang membandingkan kelompok hipotiroid nyata dengan hipotiroid subklinis. ${ }^{6,9}$

Kami mendapatkan 27 dari 68 subjek penelitian (40\%) mengalami hipotiroid primer, yang terbagi menjadi 23 hipotiroid subklinis dan 4 hipotiroid nyata. Penelitian sebelumnya melaporkan bahwa prevalensi hipotiroid nyata menunjukkan tingkat kejadian yang rendah, sebagian besar adalah hipotiroid klinis. ${ }^{5}$ Pada penelitian kami, terjadi hipotiroid subklinis pada 23 dari 68 subjek (33\%) dan sebagian besar (14 subjek) terjadi pada subjek berusia $<10$ tahun. Hasil tersebut sesuai dengan hasil penelitian sebelumnya yang melaporkan bahwa pada pasien berusia kurang dari 10 tahun lebih dominan terjadi hipotiroid subklinis. ${ }^{23}$

Sebelas dari 68 subjek penelitian (16\%) mengalami hipotiroid sekunder dan 7 dari 11 subjek penelitian terjadi pada usia $>10$ tahun. Hasil tersebut sesuai dengan penelitian sebelumnya yang melaporkan bahwa hipotiroid sekunder terjadi terutama pada subjek berusia $>10$ tahun. ${ }^{3}$ Tidak adanya peningkatan TSH terhadap rendahnya FT4 pada hipotiroid sekunder mengindikasikan insiden kerusakan tirotrop yang tinggi pada hipofisis subjek penelitian. Kerusakan yang terjadi pada hipofisis menyebabkan terganggunya respon sekresi TSH terhadap rendahnya FT4 pada pasien talasemia. Hal tersebut sudah dibuktikan pada beberapa penelitian melalui hasil MRI. ${ }^{24-26}$

Keterbatasan penelitian kami adalah data profil tiroid pada subjek penelitian saat awal terdiagnosis talasemia tidak ada.

\section{Kesimpulan}

Kadar feritin serum tidak berbeda pada penyandang talasemia dengan hipotiroid dan eutiroid, tetapi memiliki perbedaan pada hipotiroid nyata dan hipotiroid subklinis. Hasil tersebut mungkin diakibatkan adanya faktor polimorfisme pada subjek penelitian. Dengan hasil penelitian ini mendorong dilakukannya evaluasi profil tiroid secara rutin untuk mengidentifikasi hipotiroid pada penyandang talasemia sejak dini.

\section{Daftar pustaka}

1. Cao A, Galanello R. Beta-thalassemia. Genetics in Medicine 2010;12:61-76.

2. Capellini, Cohen A, Porter J, Taher A, Viprakasit V, penyunting. Guidelines for the management of transfusion dependent thalassemia (TDT). Edisi ke-3. Cyprus: Thalassemia International Federation; 2014.

3. Soliman AT, Yafei FA, Al-Naimi L, Almarri N, Yassin M, Sanctis VD. Longitudinal study on thyroid function in patients with thalassemia major: High incidence of central hypothyroidism by 18 years. 2013 .

4. Shamshirsaz AA, Bekheirnia MR, Kamgar M, Pourzahedgilani N, Bouzari N, Habibzadeh M. Metabolic and endocrinologic complications in beta-thalassemia major: a multicenter study in Tehran. BMC Endocrine Disorders 2003;3:1-6.

5. Zervas A, Katopodi A, Protonotariou A, Livadas S, Karagiorga M, Politis C. Assessment of thyroid Function in two hundred patients with b-Thalassemia Major. THYROID 2002;12:151-4.

6. Karim A, Islam M, Matin A, F D, Fakir M, Islam M. Correlation of thyroid hormone derangement with serum ferritin level in children with beta thalassaemia major at a tertiary care hospital of bangladesh. J Shaheed Suhrawardy Med Coll 2013;5:87-90. 
Burhan dkk: Perbedaan kadar feritin serum pada penyandang talasemia $\beta$ mayor hipotiroid dan eutiroid

7. Kurtoglu AU, Kurtoglu E, Temizkan K. Effect of iron overload on endocrinopathies in patients with beta-thalassaemia major and intermedia. Polish J Endocrinol 2012;63:260-3.

8. Isik P, Yarali N, Tavil B, Demirel F, Karacam B, Sac RU. Endocrinopathies in turkish children with beta thalassemia major: results from a single center study. Pediatric Hematol Oncol 2013;31:607-15.

9. Drema L, Singh P, Singh K, Pannu Ms, Kaur M, Neki NS. Thyroid profile in multi transfused children of beta thalassemia major and its correlation with serum ferritin levels. Int J Curr Res Med Sci 2017;3:14-21.

10. Pirinççioğlu AG, Deniz T, Gökalp D, Beyazıt N, Haspolat K, Söker M. Assessment of thyroid function in children aged 1-13 Years with beta-thalassemia major. Iran J Pediatr 2010;21:77-82.

11. Solanki US, Bhargava AK, Adole P. Assessment of thyroid function in multi-transfused chidlren of $\beta$ thalassemia major with iron overload. World J Pharm Pharmaceutical Sci 2014;3:2177-83.

12. Rindang C, Batubara JR, Amalia P, Satari H. Some aspects of thyroid dysfunction in thalassemia major patients with severe iron overload. Paediatrica Indonesiana 2011;51:66-72.

13. Eshragi P, Tamaddoni A, Zarifi K, Mohammadhasani A, Aminzadeh M. Thyroid function in major thalassemia patients: Is it related to height and chelation therapy? Caspian J Intern Med 2011;2:189-93.

14. Belhoul KM, Bakir ML, Saned M, Kadhim A, Musallam K, Taher A. Serum ferritin levels and endocrinopathy in medically treated patients with $\beta$ thalassemia major. Ann Hematol 2012;91:1108-14.

15. Hashemizadeh H, Noori R. Assessment of hypothyroidism in children with beta-thalassemia major in north eastern Iran. IJPHO 2012;2:123-7.

16. Bandyopadhyay S, Roychowdhury K, Chandra S DM, UB D. Variable severity of beta-thalassemia patients of eastern India: Effect of alpha-thalassemia and xmnI polymorphism. Clin Exp Med 2001;1:155-9.

17. Zacharski L, Orstein D, Woloshin S, Schwartz L. Association of age, sex, and race with body iron stores in adults: Analysis of NHANES III. Am Heart J 2000;140:98104.

18. Adams P, Reboussin D, Barton J, McLaren C, Eckfeldt J, McLaren G. Hemochromatosis and iron-overload screening in a racially diverse population. N Engl J Med 2005;352:176978.

19. Beard J, Kolb L, Rosales F, Solomons N, Angelilli M. Interpretation of serum ferritin concentrations as indicators of total-body iron stores in survey populations: the role of biomarkers for the acute phase response. Am J Clin Nutr 2006;84:1498-505.

20. Malik SA, Syed S, Ahmed N. Frequency of hypothyroidism in patients of beta thalassaemia. J Pak Med Assoc 2010;60:17-20.

21. Gulati R, Bhatia V, Agarwal S. Early onset of endocrine abnormalities in betathalassaemia major in a developing country. J Pediatr Endocrinal Metab 2000;13:651-6.

22. McAninch EA, Bianco AC. The Thr92AlaD2 polymorphism may play a novel role in hypothyroidism. Thyroid Disorders Editorial. 2015:92-4.

23. Hashemi A, Ordooei M, Golestan M, Akhavan M, Mahmoudabadi F. Hypothyroidism and serum ferritin level in patients with major $ß$ thalassemia. Iran J Pediatr Hematol Oncol 2012;2:12-5.

24. Christoforidis A, Haritandi A, Perifanis V, Tsatra I, Metaxa MA, Dimitriadis AS. MRI for the determination of pituitary iron overload in children and young adults with $\beta$ thalassaemia major. Eur J Radiol 2007;62:138-42.

25. Christoforidis A, Haritandi A, Tsitouridis I, Tsatra I, Tsantali $\mathrm{H}$, Karyda S. Correlative study of iron accumulation in liver, Myocardium, and Pituitary Assessed With MRI in Young Thalassemic Patients. J Pediatr Hematol Oncol 2006;28:311-5.

26. Murphy M, Walsh C. Thyroid function in haemochromatosis. Irish J Med Sci 2004;173:27-9. 